\title{
THERMAL ISSUES WITH THE U.S. HIGH-LEVEL WASTE REPOSITORY AND THE POTENTIAL BENEFITS OF WASTE TRANSMUTATION
}

\author{
Gordon E. Michaels \\ Oak Ridge Notional Laboratory \\ P.O. Box 2009 \\ Oak Ridge, Tennessee 37831
}

\section{INTRODUCTION}

Recent total system performance assessments for the proposed Yucca Mountain site ${ }^{2,3}$ (which assumes that spent fuel is directly emplaced in the repository without reprocessing and transmutation), have substantially altered the technical picture upon which much of the previous repository assessments were based ${ }^{11}$. The intention of this paper is to provide a qualitative update of the thermal issues associated with the proposed U.S. high-level waste repository and to discuss the potential impact of these issues. Significant questions about the ability to license the Yucca Mountain site are envisioned due to the difficulties associated with predicting the perturbations to the site that arise from the decay heat. It is suggested that waste transmutation, i.e., fuel reprocessing and use of $\mathrm{Pu}$ and other transuranic elements as fuel, may provide very significant benefits to the repository by removing the long-term heat source posed by actinides.

\section{Actinides as a Source of Repository Heat}

It is a standard assumption in repository assessments that spent fuel is emplaced after cooling times of 10 years after irradiation. At 10 years, approximately $77 \%$ of the thermal power in spent fuel originates from the decay of ${ }^{137} \mathrm{Cs}$ and ${ }^{90} \mathrm{Sr}$ and their daughters, with almost all of the remaining heat from actinide decay. In the short term, such as cooling times less than 50 years, the decay of ${ }^{90} \mathrm{Sr}$ and ${ }^{137} \mathrm{Cs}$ continues to produce the majority of the overall heat from spent fuel. However, over periods longer than 100 years, it is the alpha decay of various actinides, principally $\mathrm{Pu}$ and $\mathrm{Am}$, that dominates the total heat

\footnotetext{
Prepared by

Gordon E. Michaeis

Oak Ridge National Laboratory managed by

Lockheed Martin Energy Research, Corp. for the U.S. DEPARTMENT OF ENERGY

under Contract No. DE-AC05-96OR22464
}

\footnotetext{
"The submitted mamuscript has been authored by a contractor of the U.S. Government under contract No. DE-AC05-960R22464. Accordingly, the U.S. Government retains a nonexclusive, royalty-free license to publish or reproduce the published form of this contribution. or allow others to do so, for U.S. Government purposes."
} 
output of spent fuel. Figure 1 shows the calculated total heat energy (that is, the thermal power integrated over time) for LWR spent fuel with the actinides present and with the actinides removed. The actinides account for about $80 \%$ of the heat that is generated over the first 1000 years. For time frames beyond 1000 years, actinides contribute about $99 \%$ of the additional heat generated in a repository.

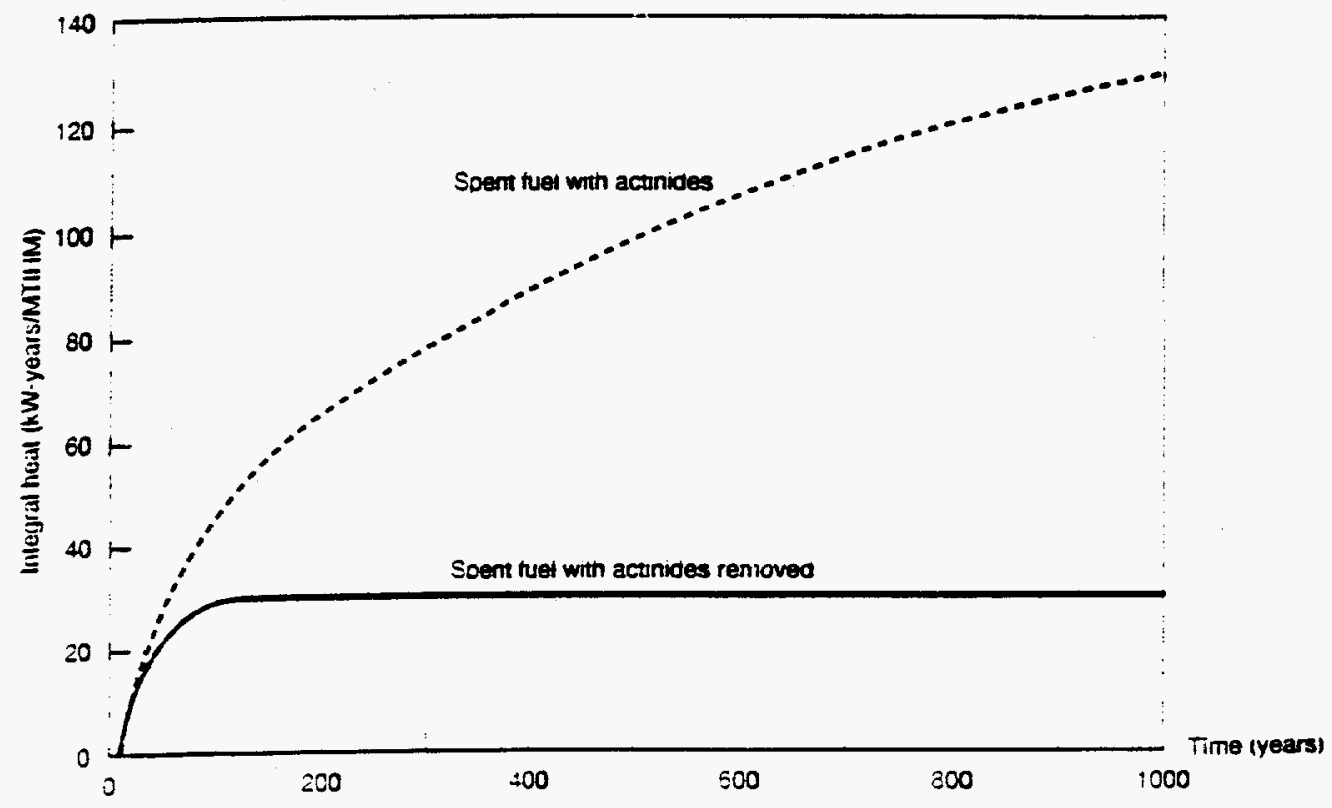

Figure 1. Total integral heat to be accommodated by a geologic repository. Heat values were calculated with ORIGEN2 model and are based on PWR fuel with an assumed burn-up of $30 \mathrm{GWd/MTIHM}$ and 10 years cooling.

These longer time frames are important, because heat is expected to move relatively slowly through the geologic media. Bulk rock temperatures in and around the repository at any given time will depend upon the heat produced over long periods of time. As an example, rock temperatures at the so-called far-field location in the geologic media (about 50 meters from the emplaced waste) is not expected to reach its peak value until 700 years after emplacement of spent fuel ${ }^{1}$. Thus, in the context of overall bulk temperatures of large volumes of the repository site, it is the decay heat of the actinides in spent fuel that is the dominate heat source, not the decay of fission products such as Cs or Sr.

\section{The Effect of Decay Heat upon Yucca Mountain}

The proposed repository at Yucca Mountain would be at an elevation of about 200 meters above the water table but at about 300 meters below the surface of the mountain. Standardly $y^{4,5}$ water is envisioned as contacting the surface of the mountain through rainfall or snowmelt and moving slowly downward through the repository region until it percolates into the aquifer, or water table, below. The standard scenario for releases from the repository involves water contacting the waste packages and accelerating their failure rate, followed by the alteration of the spent fuel by water, the subsequent dissolution of radionuclides within the groundwater, and the transport by aqueous pathways to the water 
table, where it is then assumed to have been released to an environment accessible to humans. The rock of Yucca Mountain above the water table has a moisture content that does not fill $100 \%$ of the rock pore volume; thus, it is said to be unsaturated. The relatively low level of moisture in the rock (70-90\% saturated) and the slow speed at which water is able to move through the rock to the accessible environment are aspects of the Yucca Mountain site that were originally thought to contribute to the minimization of radionuclide releases for any given emplacement period.

However, the existence of the decay heat from spent fuel is now expected to substantially perturb the unsaturated zone of Yucca Mountain. It is now reported ${ }^{2,3,6-9}$ that the hydrology and geochemistry of the site will be dominated by the heat of the spent fuel. Given the thermal-loading densities of spent fuel now considered for Yucca Mountain, a significant volume of the mountain will be raised in temperature above the boiling point of water. Thus, buoyant gas phase convection of water vapor will become an important feature of groundwater movement and of heat transport. Heat-driven buoyant vapor will transport water to a cool region above the emplaced waste where the water will condense and then be driven by gravity downward toward the repository. The resulting mountainscale convection cells between the hot, above-boiling repository and the cooler, subboiling regions will create thermo-hydrologic phenomena not currently found in the ambienttemperature site. The mountain hydrology will change significantly over thousands of years as the mountain rock first heats up after waste emplacement and then cools because of the long-term reduction of the decay heat source term.

A schematic of the potential heat-driven effects upon the Yucca Mountain hydrology at the mountain-scale is shown in Figure 2. This figure is modified from Figure 10-1 of Reference 2 and is intended to show a physical picture of the thermally-driven hydrology as it has been developed by the U.S. Yucca Mountain project. The schematic presents a snapshot in time of the mountain-scale phenomena. Some of the relevant aspects are:

- A saturated zone above the repository will arise from condensation of thermally-driven buoyant water vapor. This is often called the condensation "perch" of the repository. The size and characteristics of the perch will vary in time and spatially, according to the spatial inhomogeneity of rock characteristics and of the thermal conditions. The saturated condensation zone may be tens of meters in depth and exist over hundreds of acres within the rock.

- Depending upon assumptions, the so-called dryout zone will only include the center portion of the emplaced waste, thus exposing the edges of the repository to nearboiling liquid water. Accelerated degradation of the waste packages from subboiling liquid condensation in the end regions of the repository is a concern.

- The so-called dryout zone will probably not be absolutely dry. First, the elevation of temperatures above boiling simply converts liquid phase water into the vapor phase; but, the resulting steam will leave the above-boiling region rather slowly ${ }^{6,10}$ under most conditions and assumptions. Thus, the initial effect of heat is to create a hot (above-boiling), humid environment in which liquid film formation on the waste packages could lead to their accelerated failure. Additionally, aqueous phase water that is shed from the condensation perch will travel via fractures underneath the dryout zone and may be transported by heat pipe refluxing back into the dryout region, thus providing a mechanism for rewetting of the packages. 
- A variety of possible phenomena could cause transport of liquid phase water from the condensation perch back into the waste package region. Instabilities in the surface of the condensation cap, arising from geologic or heat source heterogeneities, may cause fracture flow of liquid phase water into the repository or enhanced imbibition of water into the local rock matrix (see Figure 2). Heat pipe effects may also affect transport of water around the condensation cap.

- The elevation of the rock to temperatures of $130^{\circ} \mathrm{C}$ or higher may cause alteration of the structure of fractures within the rock. This is important, because flow through rock fractures is currently believed to be the dominant transport mechanism for groundwater.

- Convection cells may arise within the water table. The geochemistry of the aquifer may be affected.

- $\quad$ The $\mathrm{pH}$ and chemistry of the groundwater may be greatly altered by the increase in temperatures due to the strong dependence of dissolution rates and solubility upon temperature and due to the introduction of flowing steam through the rock matrix.

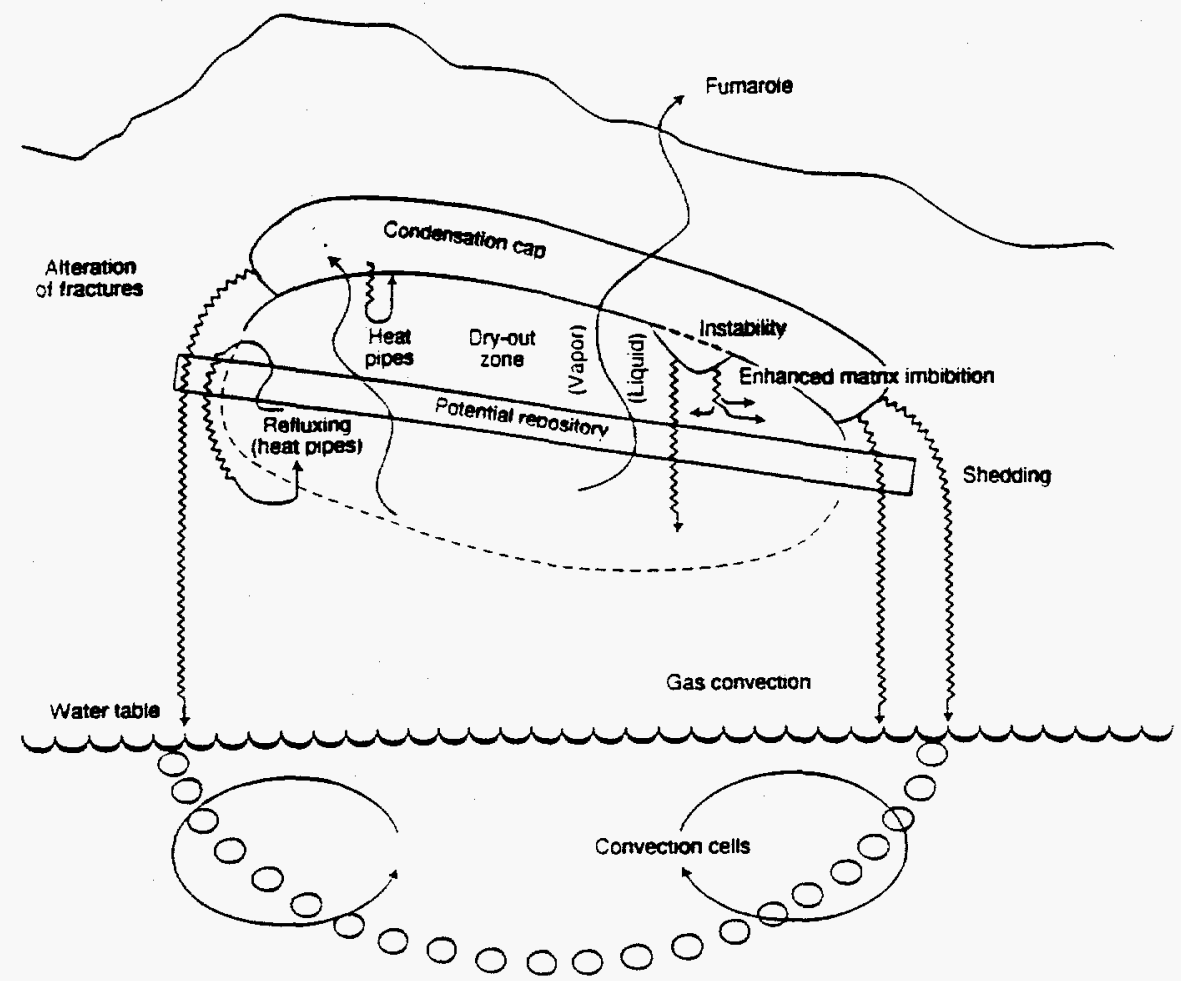

Figure 2. Schematic of thermally-driven processes that are expected to affect the hydrology of Yucca Mountain. Heat of decay of the actinides is the predominant source term that drives these processes. Some of the phenomena depicted are not yet included in repository performance calculations. Note that the so-called "dry-out zone" will actually retain non-zero levels of liquid saturation/humidity for long periods of time. Based on Figure 10-1 from Reference 2.

In addition to these mountain-scale phenomena, there will exist potentially important heat-driven phenomena at the spatial scale of the waste packages. During heatup and cooldown of the repository region, liquid phase convection cells can arise between 
neighboring waste packages, greatly altering the local groundwater hydrology. Additionally, Buscheck and $\mathrm{NitaO}^{6}$ have developed a conceptual model of heat-driven vapor and condensate flow between two neighboring packages that are in regions of sharply varying bulk permeability; i.e., one package is in relatively unfractured impermeable rock and the second package is in rock that is significantly fractured. In the Buscheck-Nitao model, vapor-phase pressure differentials drive vapor flow into the fractured rock region where it condenses and drains, possibly causing persistent two-phase refluxing conditions that may "drench" the waste package. Such phenomena may generate a need to characterize the heterogeneity of fractures in the rock over the approximately thousand acres of the repository for the 10,000 to 30,000 waste packages.

Other temperature dependent phenomena important to repository performance will also be driven by repository heat. These include: solubility of the radionuclides, rates of corrosion pitting and microbial attack of the waste package, oxidation of the spent fuel, and transport time of ${ }^{14} \mathrm{CO}_{2}$ through the repository. An example of the latter consideration is shown in Table 1.

Given the 5450 year decay half life of ${ }^{14} \mathrm{C}$, the difference in transport times of ${ }^{14} \mathrm{CO}_{2}$ from the packages to the accessible environment may be significant because of the potential for decay of the radionuclide during transport.

Table 1. Retarded Travel Times of ${ }^{14} \mathrm{C}$ from the Repository to the Atmosphere

\begin{tabular}{lc|c}
\hline $\begin{array}{l}\text { Peak Bulk Temperature } \\
\text { of Repository } \\
\text { at Release Time }\end{array}$ & \multicolumn{2}{c}{ Average ${ }^{14} \mathrm{C}$ Travel Time to Atmosphere* } \\
\cline { 2 - 3 } & tuff permeability $=10^{-11} \mathrm{~m}^{2}$ & tuff permeability $=10^{-12} \mathrm{~m}^{2}$ \\
$\sim 50^{\circ} \mathrm{C}$ & 1250 years & 11,000 years \\
& 4,500 years \\
$\sim 130^{\circ} \mathrm{C}$ & 250 years & \\
\hline
\end{tabular}

* Values of travel time are derived from Figures 12-5 and 12-8 of Reference 2.

Temperature values were obtained from Figure 12-6 of the same reference.

\section{Implications of Actinide Heat for Repository Licensing}

Licensing of a hot repository will require extensive analysis and characterization of a massively perturbed geologic system. Essentially, site characterization studies can only characterize the properties, hydrology, and chemistry of the unperturbed system. The licensing effort will need to rely upon computer models to extrapolate the existing mountain system to the massive-perturbed system that must be relied upon for isolation of the wastes from the accessible environment. Small-scale experiments may be able to provide helpful information, but the spatial scale of many of the discussed phenomena would appear to make their experimental characterization impractical. Thus, computer modeling will be required as a licensing basis. 
For repositories that are above-boiling or near-boiling in temperature, the fact that heat transport will likely be dominated by multiphase convective processes rather than by conduction $^{6}$ will require enormously greater complexity in calculations of temperature. Similarly, the transport of water and radionuclides in these systems will be driven by nonisothermal, multiphase flow with critically important ${ }^{7.8}$ nonequilibrium flow processes between the fractures and the rock matrix. The modeling of these phenomena will require theoretical advances in flow modeling ${ }^{6}$.

Another aspect of the effects of actinide heat upon the repository is the potential importance of heterogeneity to the performance calculations. The requirements for characterizing the heterogeneity of the mountain are unclear, but may well be very costly, and might be impractical. The issue of heterogeneity is further complicated by the possibility of heat altering the properties of the media; i.e., by alteration of fractures.

The temporal nature of the thermally-driven perturbation to the mountain system also introduces unfavorable complexity into the licensing process. Calculations by Buscheck and $\mathrm{Nitao}^{9}$ indicate that repository heat-driven changes in the hydrology can persist for more than 100,000 years. The licensing requirements are expected to call for characterization of the performance of the mountain over a time period of 10,000 years or longer.

The combination of these factors: (1) theoretically complex heat transport and flow phenomena; (2) the importance of heterogeneity; (3) the diverse spatial scales of the processes, and (4) the long time periods over which the phenomena must be described, may make the licensing of Yucca Mountain very complex. Indeed, the current licensing strategy of the repository may be characterized as relying upon unprecedented success at modeling of very complex phenomena for very long periods of time which are sensitive to small-scale heterogeneities.

In this context, it may be that destruction of the actinides by transmutation with either accelerator-driven systems or in reactors, in combination with longer surface cooling times for $\mathrm{Cs}$ and $\mathrm{Sr}$, would permit the emplacement of waste in an ambient-temperature repository that might be licensed in a more rapid and cost-effective manner. This "cold" repository concept would need to be studied further to determine its benefits and to define the requirements for actinide burning. It seems likely that the actinides would not need to be completely eliminated from the repository, but that reduction in actinide quantity by more than a factor of 10 , but less than a factor of 100 , might be required. Thus, transmutation systems would not need to address every waste stream that is to be emplaced in the repository in order to achieve the benefits of a cold repository - but only the majority of the actinide-bearing streams. This simplification is a potentially important aspect of a transmutation-enabled "cold" repository concept.

The projected benefits of a "cold" repository may be fully achievable only if both farfield and near-field temperatures are maintained at subboiling levels. Thus, transmutationenabled cold repository concepts may require surface cooling times for $\mathrm{Cs}$ and $\mathrm{Sr}$ that are longer than 10 years in order to meet near-field temperature limits. This may be a potential problem for the cold repository concept and needs further study. Surface storage time requirements up to 50 years may be acceptable, and indeed may match well the lag storage 
times that will be required anyway as transmutation systems are developed, constructed, and brought into operation. However, $\mathrm{Cs}$ and $\mathrm{Sr}$ storage times greatly in excess of 50 years may present institutional issues for a transmutation-enabled cold repository concept. Clearly, better quantification of cooling time requirements for $\mathrm{Cs}$ and $\mathrm{Sr}$ are needed.

Methods other than actinide transmutation may exist for avoiding the above-mentioned thermal complexity issues. These methods may include:

- finding a repository waste emplacement strategy and configuration for which the repository performance is insensitive to the theoretically difficult aspects of heat transport and flow that are expected for the hot repository.

- decreasing the areal loading density of waste to maintain repository temperatures below the threshold for buoyant gas-phase flow processes. This repository strategy must result in temperatures that are significantly below "subboiling," e.g., peak temperatures below $70^{\circ} \mathrm{C}$. This option would have unfavorable impacts on repository capacity.

The discussion of these other options is beyond the scope of this paper.

\section{CONCLUSIONS}

Many potentially important features, processes, and events have yet to be included in repository performance models, and many model simplifications have not yet been evaluated to determine whether they underestimate radionuclide releases. For this reason, it is premature to dismiss the radionuclide releases from the Yucca Mountain site as being acceptably low. Quantitative evaluations of the omitted phenomena are needed to determine whether the proposed Yucca Mountain repository will pose an acceptable health risk to the public.

Licensing of a repository at the Yucca Mountain site may be very expensive and may be uncertain of success due to the substantial perturbations to the mountain hydrology and geology caused by actinide decay heat. The heat of the actinides may have the following implications:

- heat transfer calculations will not be focused upon theoretically-simple conduction processes, but instead will address multiphase, convective processes that are sensitive to spatial variability in the heat source term and in the geologic medium properties.

- groundwater transport calculations will not be based solely on currently observable figures-of-merit such as groundwater percolation rates. Instead, thermally-driven processes will dominate the hydrology, and the licensing process will need to extrapolate multiphase flow processes with critically important disequilibrium processes between fractures and the rock matrix. These calculations will likely be sensitive to spatial variations in geologic media properties over hundreds of acres and may depend upon ability to forecast thermally-induced alterations of fractures in the mountain.

- these theoretically-difficult processes will vary in time, and thus modeling of the massively perturbed mountain system must be performed for periods of 10,000 years or greater. 
Transmutation of actinides, in combination with longer cooling times for ${ }^{137} \mathrm{Cs}$ and ${ }^{90} \mathrm{Sr}$, may create an opportunity to design a relatively high capacity repository with peak temperatures below $70^{\circ} \mathrm{C}$. Such a cold repository concept requires significant additional evaluation to determine whether it offers significant benefits. However, transmutation-enabled cold repositories have an intuitive appeal, because their licensing may be more directly based upon currently observable characteristics of the site and because their licensing may not depend upon unprecedented success with modeling of very complex phenomena over very long periods of time which are sensitive to small-scale system heterogeneities.

\section{REFERENCES}

1. Croff, A. G., "A Concept for Increasing the Effective Capacity of a Unit Area of a Geologic Repository," Radioactive Waste Management and the Nuclear Fuel Cycle (June 1994).

2. Wilson, M., et al., Total-System Performance Assessment for Yucca Mountain - SNL Second Iteration (TSPA-1993), SAND93-2675, Sandia National Laboratories (April 1994).

3. Andrews, R. W., T. F. Dale, and J. A. McNeish, Total System Performance . Assessment - 1993: An Evaluation of the Potential Yucca Mountain Repository, B00000000-01717-2200-00099-Rev.01, INTERA, Inc., Las Vegas, NV (March 1994).

4. Barnard, R. W., et al., "TSPA 1991: An Initial Total-System Performance Assessment for Yucca Mountain," SAND91-2795, Sandia National Laboratories, Albuquerque, NM (1992).

5. Pacific Northwest Laboratory, Preliminary Total-System Analysis of a Potential HighLevel Nuclear Waste Repository at Yucca Mountain, PNL-8444, Richland, Washington, Westinghouse Hanford Company (January 1993).

6. Buscheck, T. A., and J. J. Nitao, "The Impact of Buoyant, Gas-Phase Flow and Heterogeneity on Thermo-Hydrological Behavior at Yucca Mountain," American Nuclear Society, Proceedings of the Fifth Annual International High Level Radioactive Waste Management Conference, Vol. 4, pp. 2450-2474, Las Vegas, NV (May 22-26, 1994).

7. Buscheck, T. A., J. J. Nitao, and D. A. Chesnut, "The Impact of Episodic Nonequilibrium Fracture-Matrix Flow on Geological Repository Performance," Proceedings American Nuclear Society Topical Meeting on Nuclear Waste Packaging (Focus 91), Las Vegas, NV, September 30-October 2, 1991. Also, UCRL-JC-106759, Lawrence Livermore National Laboratory, Livermore, CA (1991).

8. Nitao, J. J., T. A. Buscheck, and D. A. Chesnut, "Implications of Episodic Nonequilibrium Fracture-Matrix Flow on Repository Performance," Nuclear Technology, Vol. 104, No. 3, pp. 385-402 (1993). 
9. Buscheck, T. A., and J. J. Nitao, "The Impact of Thermal Loading on Repository Performance at Yucca Mountain," American Nuclear Society, Proceedings Third International High-Level Radioactive Waste Management Conference, Las Vegas, NV, April 12-16, 1992. Also, UCRL-JC-109232, Lawrence Livermore National Laboratory, Livermore, CA (1992).

10. Mishra, Srikanta, "Far-Field Thermohydrologic Calculations," Appendix A in Total System Performance Assessment - 1993: An Evaluation of the Potential Yucca Mountain Repository, B00000000-01717-2200-00099-Rev.01, INTERA, Inc., Las Vegas, NV (March 1994).

11. Michaels, G. E., "Potential Benefits of Waste Transmutation to the U.S. High-Level Waste Repository," in Proceedings of the International Conference on AcceleratorDriven Transmutation Technologies and Applications, Las Vegas, NV

(July 25-29,1994).

\section{DISCLAIMER}

\footnotetext{
This report was prepared as an account of work sponsored by an agency of the United States
Government. Neither the United States Government nor any agency the employees, makes any warranty, express or implied nor any agency thereof, nor any of their bility for the accuracy, completeness, or usefulness, or assumes any legal liability or responsiprocess disclosed, or represents that its use would of any information, apparatus, product, or ence herein to any specific commercial pre would not infringe privately owned rights. Refermanufacturer, or otherwise does not necessarily constitute or service by trade name, trademark, mendation, or favoring by the United States Govenstitute or imply its endorsement, recomand opinions of authors expressed herein do novernment or any agency thereof. The views United States Government or any agency thereof.
} 